\title{
DAYA PSIKOLOGIS MAHASISWA S1 UNIVERSITAS PENDIDIKAN INDONESIA
}

\author{
1) Tina Hayati Dahlan \\ ${ }^{1}$ Departemen Psikologi, Fakultas Ilmu Pendidikan Universitas Pendidikan Indonesia \\ Email:tinadahlan@gmail.com
}

\begin{abstract}
Writing this article aims to describe the empirical data on student psychological power S1 UPI that includes psychological problems in fulfilling the needs and competencies of intrapersonal and interpersonal competence as elements that build psychological power. This study was conducted in 2011 using quantitative descriptive method to sample as many as 585 students S1 UPI selected using non probability sampling techniques. The results showed that at the university level and faculty, the highest percentage in the fulfillment of psychological problems is not free in the choice of life and does not understand the responsibilities attached to the selection. Psychological power level students in general are in a category average, the percentage of students who have psychological power below the average higher than the above average, as well as the distribution of competence intrapersonal and interpersonal competence. The percentage of students FPBS and FPMIPA with power levels of psychological, interpersonal competence, and interpersonal competencies under average considerably higher than students with psychological power levels above the average; while the percentage of students FIP and FPTK with power levels of psychological, interpersonal competence and interpersonal competence above average much higher than students with psychological power levels below average.
\end{abstract}

Keywords: psychological power, psychological, interpersonal competence, interpersonal competence.

\section{A.PENDAHULUAN}

Kehidupan menjadi mahasiswa di suatu perguruan tinggi memberi peluang dan kesempatan kepada mahasiswa untuk menikmati kemandirian dari pengawasan orang tua ataupun orang dewasa lainnya. Hal ini ditunjukkan antara lain dengan adanya peluang untuk berinteraksi dengan teman sebaya yang berasal dari berbagai geografis dan latar belakang etnis, adanya mata kuliah yang dapat dipilih mahasiswa, dan banyaknya unit kegiatan mahasiswa dalam lingkup yang luas.

$\begin{array}{rrr}\text { Dalam } & \begin{array}{r}\text { kehidupan } \\ \text { mereka }\end{array} & \begin{array}{r}\text { sebagai } \\ \text { akan }\end{array}\end{array}$ menghadapi tekanan sosial dan akademis yang memaksa mereka untuk memegang berbagai peran yang seringkali melibatkan tanggung jawab yang lebih besar. Prestasi menjadi pokok persoalan yang lebih serius karena mereka mulai memandang keberhasilan dan kegagalan saat ini sebagai prediktor bagi keberhasilan dan kegagalan di masa dewasa nanti. (Eccles dan Wigfield, 2000; Henderson dan Dweck, 1990; Wigfield dan kawankawan, 2006; dalam Santrock, 2007).

Dalam menghadapi tekanan di perguruan tinggi, dapat diasumsikan terdapat mahasiswa yang mengatasinya dengan cara yang efektif dan konstruktif dan terdapat pula mahasiswa yang mengatasinya dengan cara destruktif sampai menghambat proses pembelajaran dan kemajuan studinya. 


\section{B.KAJIAN LITERATUR}

Keefektifan individu dalam mengatasi permasalahan dan tekanan dipengaruhi oleh daya psikologis (Cavanagh dan Levitov, 2002: 192) yang dibangun oleh 3 (tiga) unsur yang saling berkaitan, yaitu: (1) pemenuhan kebutuhan psikologis, (2) kompetensi intrapersonal, dan (3) kompetensi interpersonal. Keterkaitan antara ketiga unsur ini penting bagi berfungsinya unsur itu sendiri serta dua unsur lainnya sehingga perubahan dalam satu unsur akan diikuti oleh perubahan dalam unsur yang lain. Semakin baik kompetensi intrapersonal dan interpersonal, maka semakin tinggi tingkat pemenuhan kebutuhan psikologis mereka serta semakin efektif dan konstruktif cara mereka mengatasi permasalahan dan tekanan. Sebaliknya, semakin buruk kompetensi intrapersonal dan interpersonal, maka semakin rendah tingkat pemenuhan kebutuhan psikologis serta semakin tidak efektif dan konstruktif cara mereka mengatasi permasalahan dan tekanan. Dengan kata lain, rendahnya kompetensi intrapersonal dan interpersonal mahasiswa akan menyebabkan munculnya permasalahan dalam pemenuhan kebutuhan psikologis dan cara mereka dalam mengatasi permasalahan dan tekanan sosial maupun akademis.

Penelitian ini bertujuan untuk memperoleh data empiris tentang permasalahan dalam pemenuhan kebutuhan psikologis serta kompetensi interpersonal dan kompetensi interpersonal sebagai unsur-unsur yang membangun daya psikologis. Permasalahan dalam pemenuhan kebutuhan psikologis yang dimaksud dalam penelitian ini meliputi: (1) enggan untuk memberikan perhatian dan kasih sayang kepada orang lain serta merasa tidak menerima kasih sayang dan perhatian dari orang lain; (2) tidak bebas dalam menentukan pilihan dalam hidup serta tidak memahami tanggung jawab yang melekat pada pilihan tersebut; (3) melakukan rutinitas yang sama tanpa diselingi kegiatan yang bersifat refreshing atau rekreasi; (4) pasif dalam mencari tantangan-tantangan dan sesuatu yang baru dalam hidup, (5) tidak melihat hasil positif dari suatu usaha sehingga sulit untuk mencapai kepuasan; (6) memandang suatu situasi hanya dari satu sudut pandang, (7) tidak memiliki waktu untuk berintrospeksi; dan (8) memiliki tujuan hidup yang tidak jelas dan tidak terarah.

\section{METODE PENELITIAN}

Metode yang digunakan dalam penelitian ini adalah metode deskriptif kuantitatif yang bertujuan untuk mendeskripsikan distribusi frekuensi persentase permasalahan dalam pemenuhan kebutuhan psikologis serta kompetensi interpersonal dan kompetensi interpersonal sebagai unsur-unsur yang membangun daya psikologis.

Sampel penelitian berjumlah 585 mahasiswa yang dipilih dengan menggunakan teknik non probability sampling terhadap mahasiswa $\mathrm{S} 1$ UPI dari tujuh fakultas di UPI, yaitu Fakultas Ilmu Pendidikan (FIP) sejumlah 86 orang, Fakultas Pendidikan Bahasa dan Sastra (FPBS) sejumlah 95 orang, Fakultas Ekonomi dan Bisnis (FPEB) sejumlah 102 orang, Fakultas Pendidikan Ilmu Pengetahun Sosial (FPIPS) sejumlah 80 orang, Fakultas Pendidikan Matematika dan Ilmu Pengetahuan Alam (FPMIPA) 
sejumlah 108 orang, Fakultas Pendidikan Olahraga dan Kesehatan (FPOK) sejumlah 42 orang, dan Fakultas Pendidikan Teknologi dan Kejuruan (FPTK) sejumlah 72 orang. Instrumen yang digunakan dalam penelitian ini disusun oleh peneliti yang terdiri atas instrumen untuk menjaring data permasalahan dalam pemenuhan kebutuhan psikologis dan daya psikologis yang indikator-indikatornya diturunkan dari atribut kompetensi intrapersonal dan kompetensi interpersonal sebagai unsur-uns ur yang membangun daya psikologis.
Hasil uji reliabilitas dengan menggunakan Alpha Cronbach terhadap instrumen untuk mengukur daya psikologis diperoleh koefisien realibilitas untuk daya psikologis sebesar $\alpha=0,912$, sementara untuk kompetensi intrapersonal sebesar $\alpha=$ 0,885 dan untuk kompetensi interpersonal sebesar $\alpha=0,808$.

\section{HASIL PENELITIAN \\ Profil Permasalahan dalam Pemenuhan Kebutuhan Psikologis pada Mahasis wa S1 UPI}

\section{Tingkat Universitas}

Grafik 1 mengilustrasikan profil permasalahan dalam pemenuhan kebutuhan psikologis pada mahasiswa S1 UPI.

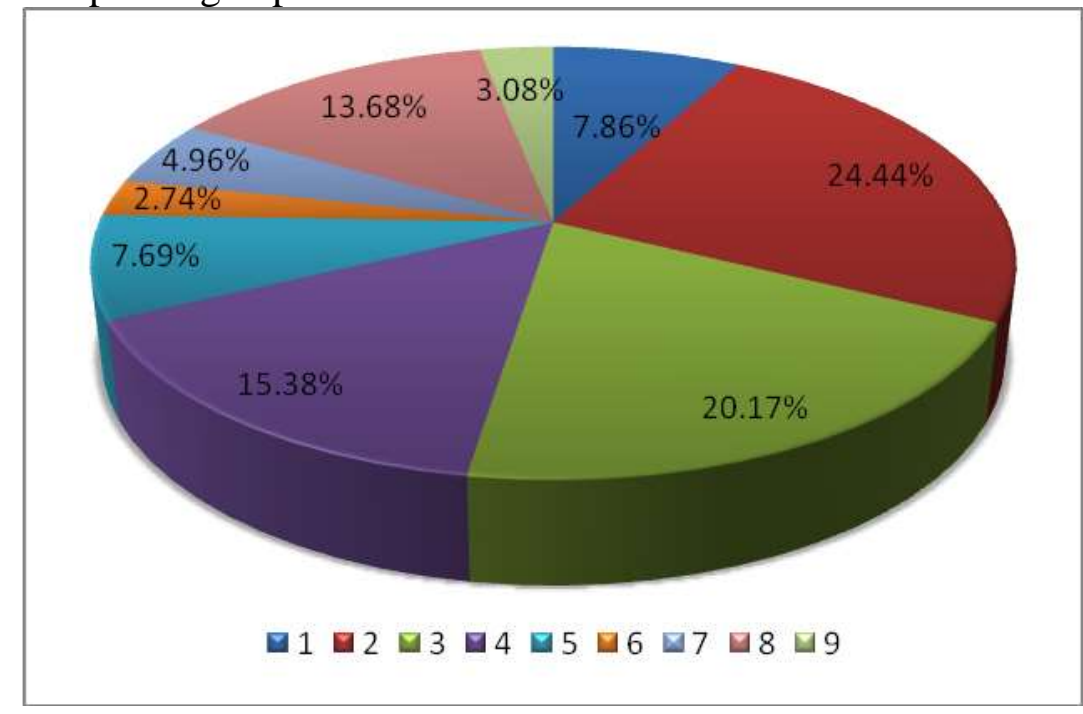

Grafik 1

Profil Permasalahan dalam Pemenuhan Kebutuhan Psikologis pada Mahasiswa S1 UPI di Tingkat Universitas

Grafik 1 menunjukkan bahwa permasalahan dalam pemenuhan kebutuhan psikologis pada mahasiswa S1 UPI dari persentase tertinggi sampai terendah yaitu $24,4 \%$ mahasiswa tidak bebas dalam menentukan pilihan dalam hidup serta tidak memahami tanggung jawab yang melekat pada pilihan tersebut; 20,17\% mahasiswa melakukan rutinitas yang sama tanpa diselingi kegitan yang bersifat refreshing atau rekreasi; $15,38 \%$ mahasiswa pasif dalam mencari tantangan-tantangan dan sesuatu yang baru dalam hidup; $13,68 \%$ mahasiswa memiliki tujuan hidup yang tidak jelas dan tidak terarah, 7,86\% mahasiswa enggan untuk memberikan perhatian dan kasih 
sayang kepada orang lain serta merasa tidak menerima kasih sayang dan perhatian dari orang lain; 7,69\% mahasiswa tidak melihat hasil positif dari suatu usaha sehingga sulit untuk mencapai kepuasan; 4,96\% mahasiswa tidak memiliki waktu untuk berintrospeksi; $2,74 \%$ mahasiswa memandang suatu situasi hanya dari satu sudut pandang; dan 3,08\% mahasiswa berpendapat bahwa permasalahan dalam aspek kebutuhan psikologis tidak menimbulkan kesulitan bagi mereka.

Urutan pertama, kedua, dan ketiga permasalahan dalam pemenuhan kebutuhan psikologis yang dianggap paling menganggu mahasiswa disajikan dalam

Grafik

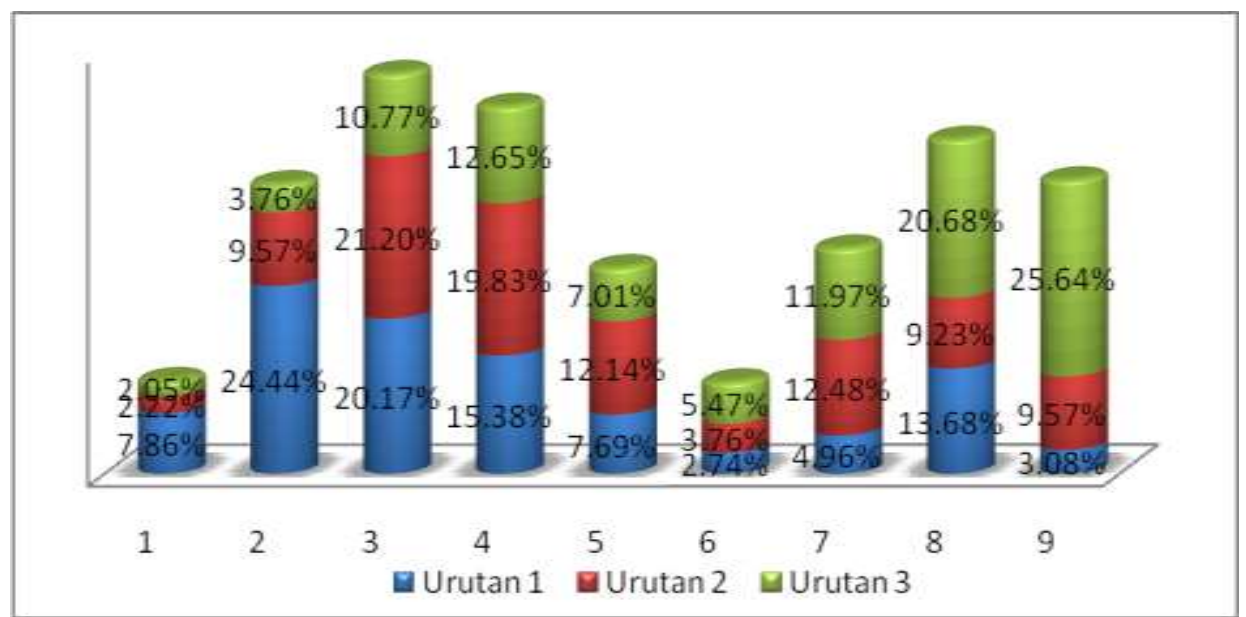

Grafik 2

Profil Permasalahan dalam Kebutuhan Psikologis Berdasarkan Urutan ke-1 s.d ke-3

Grafik 2 menunjukkan

bahwa persentase tertinggi sebagai permasalahan urutan pertama adalah tidak bebas dalam menentukan pilihan dalam hidup serta tidak memahami tanggung jawab yang melekat pada pilihan menempati. Untuk permasalahan urutan kedua, melakukan rutinitas yang sama tanpa diselingi kegitan yang bersifat refreshing atau rekreasi menempati persentase tertinggi; sedangkan untuk permasalahan urutan ketiga, memiliki tujuan hidup yang tidak je las dan tidak terarah menempati persentase tertinggi. 


\section{Tingkat Fakultas}

Grafik

mengilustrasikan permasalahan dalam pemenuhan kebutuhan psikologis pada mahasiswa S1 UPI di tingkat fakultas.

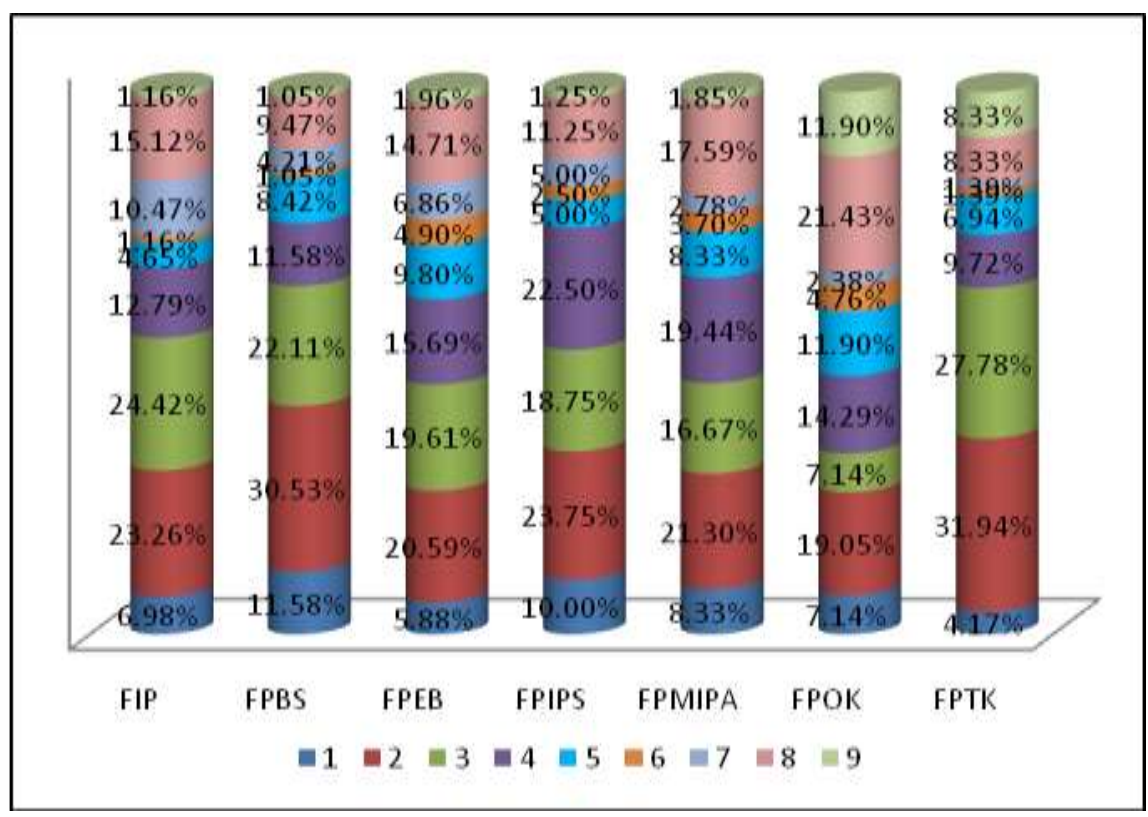

Grafik 4.3

Profil Permasalahan dalam Pemenuhan Kebutuhan Psikologis pada Mahasiswa S1 UPI di Tingkat Fakultas

\section{Permasalahan}

mahasiswa yang menempati pesentase tertinggi di FIP adalah pemenuhan kebutuhan untuk melakukan kegiatan yang bervariasi untuk mengatasi rasa bosan dan rasa sakit; sedangkan permasalahan mahasiswa di enam fakultas lainnya sama dengan permasalahan di tingkat universitas, yaitu permasalahan pada pemenuhan kebutuhan untuk me miliki sejumlah pilihan bebas yang layak dalam kehidupan mereka serta memahami tanggung jawab tertentu yang melekat pada pilihan tersebut.

Profil Tingkat Daya Psikologis Mahas is wa S1 UPI

\section{Tingkat Universitas}

Profil tingkat daya psikologis mahasiswa $\mathrm{S} 1$ UPI di tingkat universitas diilustrasikan pada Grafik 4. 


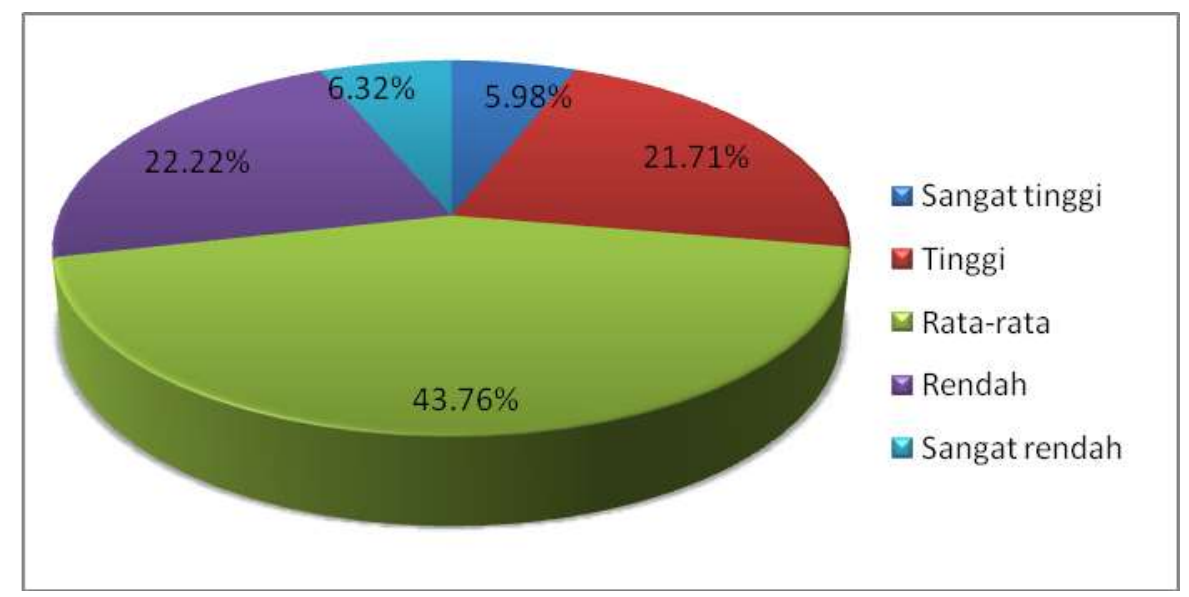

Grafik 4

Profil Tingkat Daya Psikologis Mahasiswa S1 UPI di Tingkat Universitas

Grafik 4 menunjukkan bahwa tingkat daya psikologis mahasiswa S1 UPI pada umumnya berada dalam kategori rata-rata $(43,76 \%)$ dengan persentase tingkat daya psikologis di bawah rata-rata lebih tinggi dibandingkan yang di atas rata-rata.

2. Tingkat Fakultas

Profil tingkat daya psikologis mahasiswa S1 UPI di tingkat fakultas disajikan pada Grafik 5. 


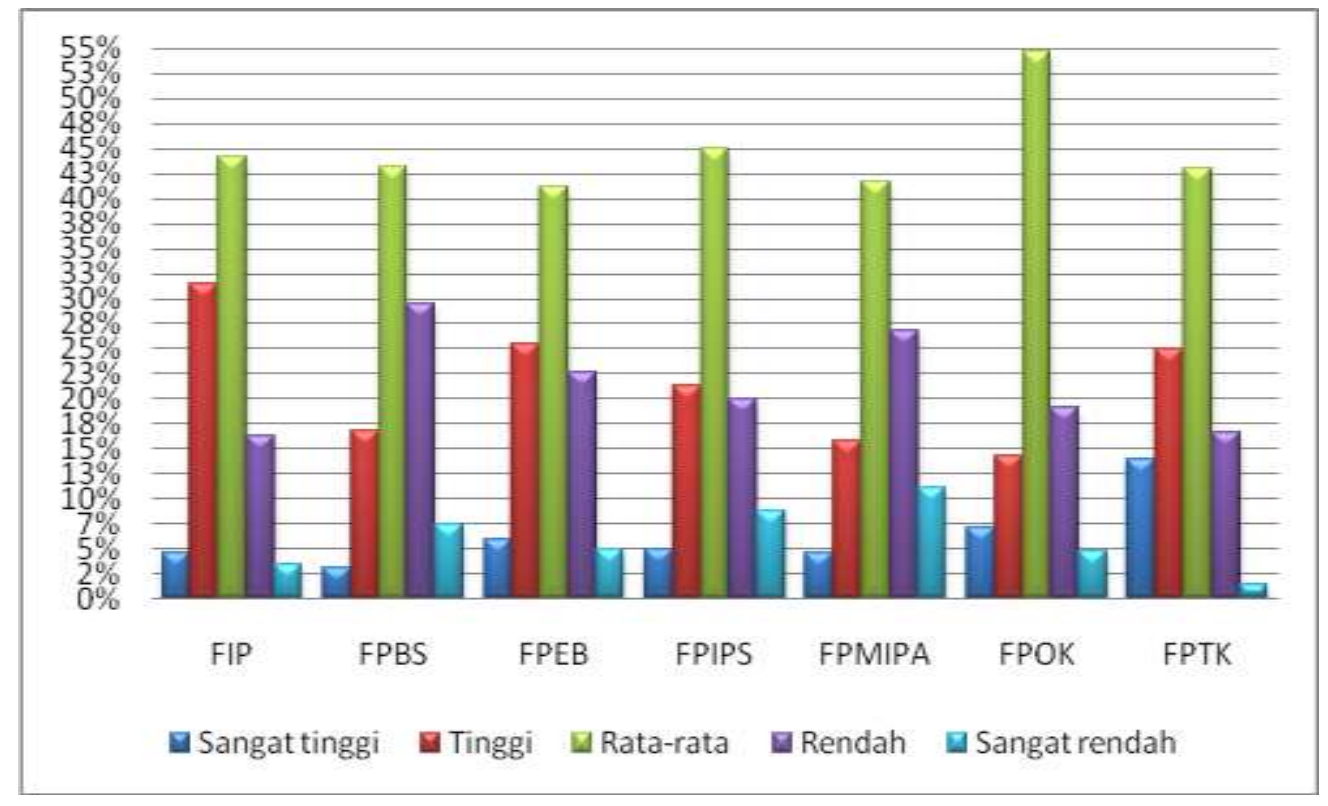

Grafik 5

Profil Tingkat Daya Psikologis Mahasiswa S1 UPI di Tingkat Fakultas

Grafik 5 menunjukkan bahwa mahasiswa FPBS dan FPMIPA dengan tingkat daya psikologis di bawah rata-rata jauh lebih banyak dibandingkan mahasiswa dengan tingkat daya psikologis di atas rata-rata; sedangkan mahasiswa FIP dan FPTK dengan tingkat daya psikologis di atas rata-rata jauh lebih banyak dibandingkan mahasiswa dengan tingkat daya psikologis di bawah rata-rata.

Profil Tingkat Kompetensi Intrapersonal Mahasiswa S1 UPI

\section{Tingkat Universitas}

Profil tingkat kompetensi intrapersonal mahasiswa S1 UPI di tingkat universitas diilustrasikan pada Grafik 6.

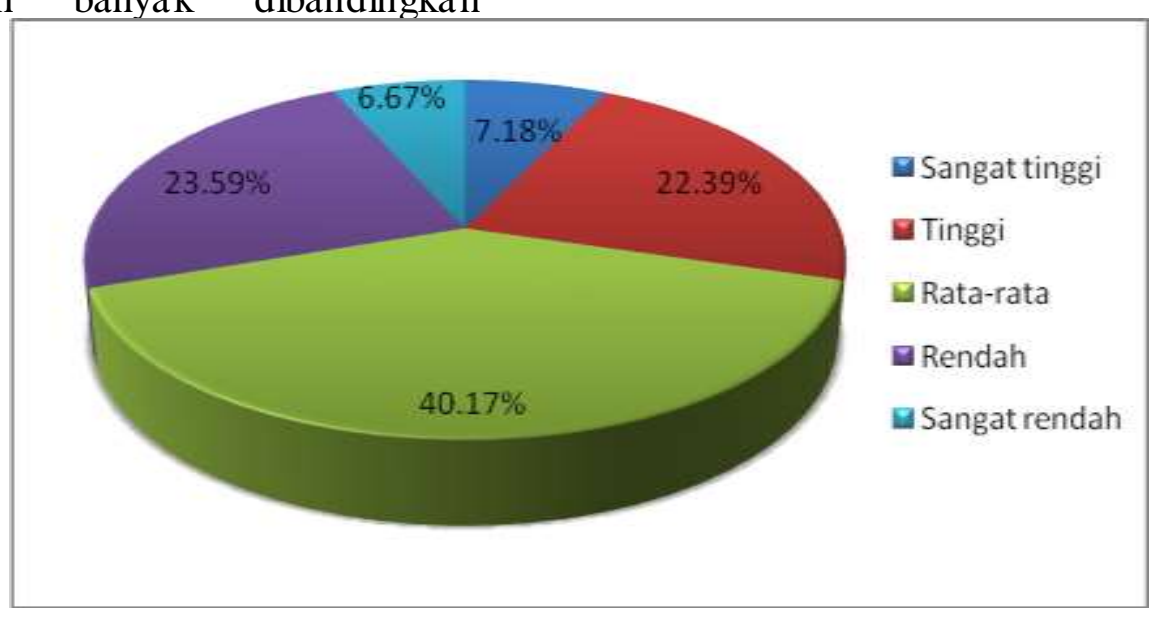


Profil tingkat kompetensi intrapersonal mahasiswa S1 UPI di tingkat fakultas disjaikan pada Grafik 7.

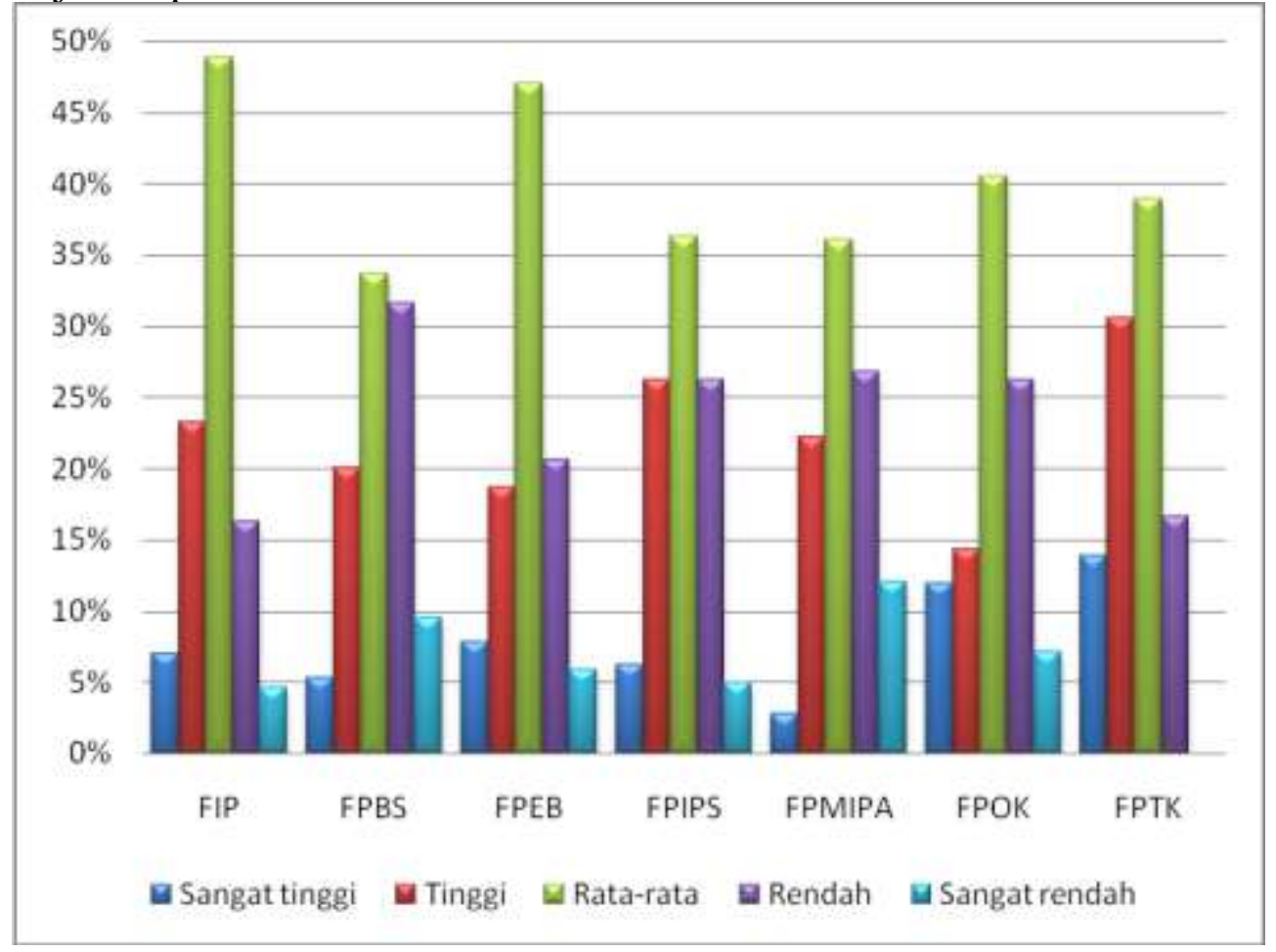

Grafik 7

Profil Tingkat Kompetensi Intrapersonal Mahasiswa S1 UPI Tingkat Fakultas

Grafik 7 menunjukkan

bahwa persentase mahasiswa FPBS dan FPMIPA dengan tingkat kompetensi intrapersonal di bawah rata-rata jauh lebih banyak dibandingkan mahasiswa dengan tingkat kompetensi intrapersonal di atas rata-rata; sedangkan persentase mahasiswa FIP dan FPTK dengan tingkat kompetensi intrapersonal di atas rata-rata jauh lebih banyak dibandingkan mahasiswa dengan tingkat kompetensi intrapersonal di bawah rata-rata. Bahkan di FPTK, persentase mahasiswa yang memiliki tingkat kompetensi intrapersonal kategori sangat rendah sebesar 0\%. Di FPEB, persentase antara mahasiswa dengan tingkat kompetensi intrapersonal di bawah rata-rata dengan yang di atas rata-rata menunjukkan keadaan seimbang.

Profil Tingkat Kompetensi Interpersonal Mahasiswa S1 UPI

\section{Tingkat Universitas}

Profil tingkat kompetensi interpersonal mahasiswa S1 UPI di tingkat universitas disajikan pada Grafik 8. 


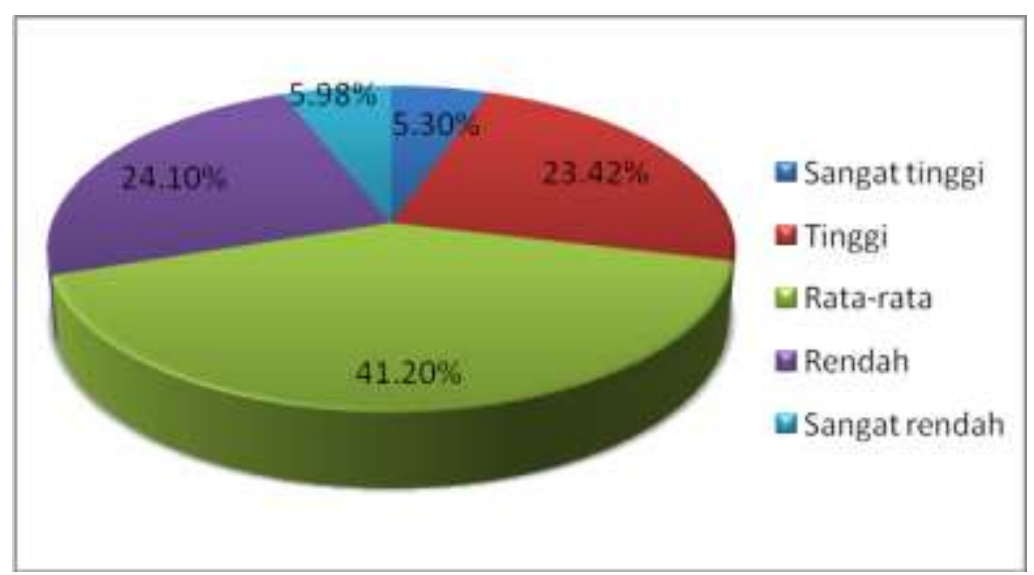

Grafik 8

Profil Tingkat Kompetensi Interpersonal Mahasiswa S1 UPI di Tingkat Universitas

dibandingkan yang di atas rata-

Grafik 8 menunjukkan bahwa pada umumnya mahasiswa memiliki tingkat kompetensi interpersonal kategori rata-rata $(41,20 \%)$ dan persentase mahasiswa yang memiliki tingkat kompetensi interpersonal kategori di bawah rata-rata lebih besar rata.

\section{Tingkat Fakultas}

Profil tingkat kompetensi interpersonal mahasiswa S1 UPI di tingkat fakultas dapat dilihat pada Grafik 9.

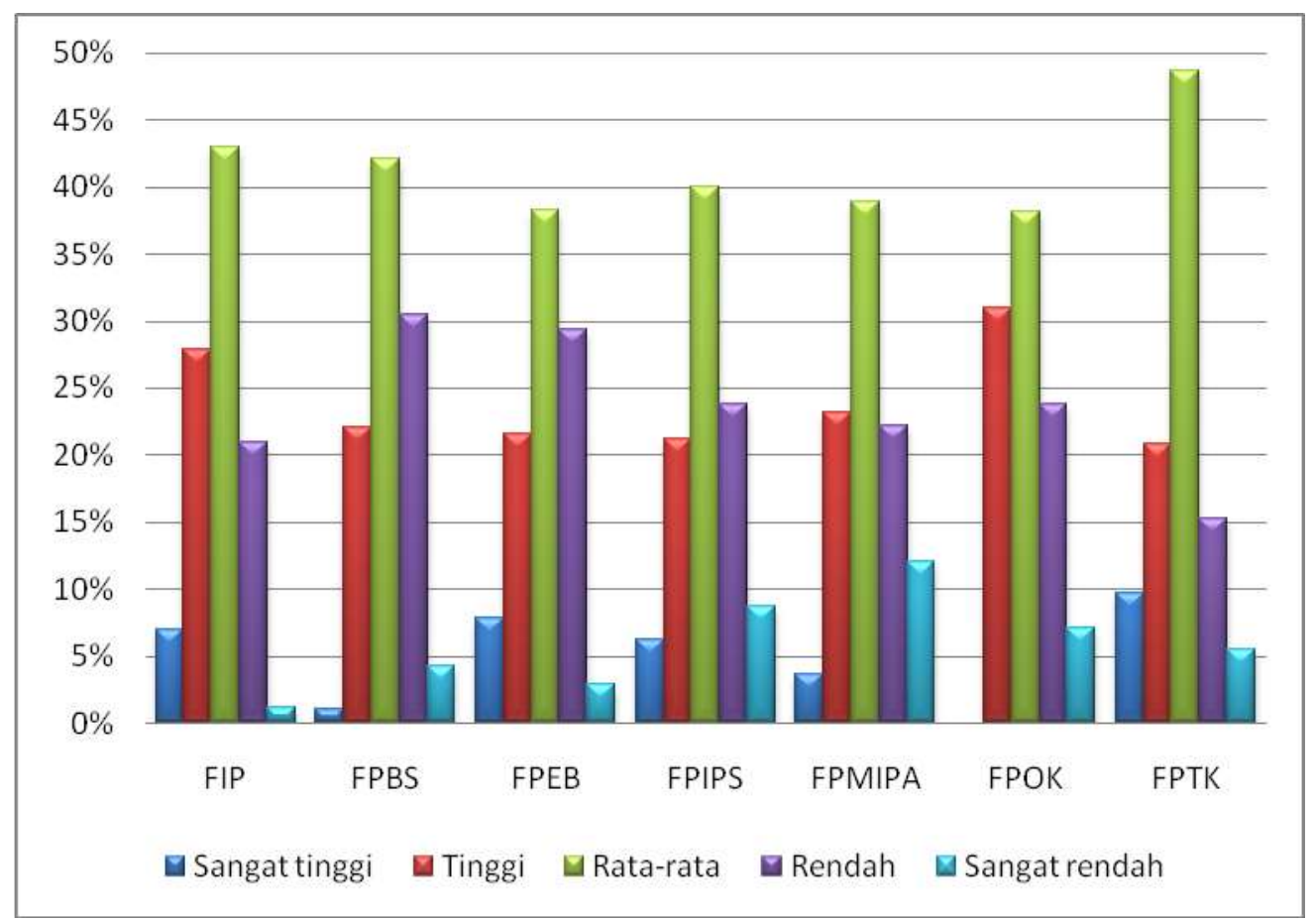


Grafik 9

Profil Tingkat Kompetensi Interpersonal Mahasiswa S1 UPI di Tingkat

Fakultas

rata-rata dengan persentase kategori

$\begin{array}{rrr}\text { Grafik } 9 & \text { menunjukkan } \\ \text { bahwa } & \text { bahwa } & \text { persentase }\end{array}$ mahasiswa FPBS, FPIPS dan FPMIPA dengan tingkat kompetensi interpersonal di bawah rata-rata jauh lebih tinggi dibandingkan persentase mahasiswa dengan tingkat kompetensi interpersonal di atas rata-rata; sedangkan persentase mahasiswa FIP dan FPTK dengan tingkat kompetensi interpersonal di atas rata-rata jauh lebih tinggi dibandingkan persentase mahasiswa dengan tingkat kompetensi interpersonal di bawah rata-rata. Di FPOK, persentase antara mahasiswa dengan tingkat kompetensi interpersonal di bawah rata-rata dengan yang di atas rata-rata menunjukkan keadaan seimbang.

\section{E. KESIMPULAN DAN REKOMENDASI}

Penelitian ini memperoleh hasil bahwa persentase tertinggi pada permasalahan dalam pemenuhan kebutuhan psikologis dan persentase tertinggi sebagai permasalahan urutan pertama yang dimiliki mahasiswa S1 UPI baik di tingkat universitas ataupun di tingkat fakultas (kecuali di FIP) adalah tidak bebas dalam menentukan pilihan dalam hidup serta tidak memahami tanggung jawab yang melekat pada pilihan tersebut.

Tingkat daya psikologis termasuk kompetensi intrapersonal dan kompetensi interpersonal pada mahasiswa S1 UPI untuk tingkat unversitas berada dalam kategori di bawah rata-rata lebih tinggi dibandigkan yang di atas rata-rata.

Persentase mahasiswa FPBS dan FPMIPA dengan tingkat daya psikologis kompetensi intrapersonal, dan kompetensi interpersoanl (termasuk FPIPS) di bawah rata-rata jauh lebih tinggi dibandingkan mahasiswa dengan tingkat daya psikologis di atas rata-rata; sedangkan persentase mahasiswa FIP dan FPTK dengan tingkat daya psikologis, kompetensi intrapersonal, dan kompetensi interpersonal di atas rata-rata jauh lebih banyak dibandingkan mahasiswa dengan tingkat daya psikologis di bawah rata-rata. Bahkan di FPTK, persentase mahasiswa yang memiliki tingkat kompetensi intrapersonal kategori sangat rendah sebesar $0 \%$. Temuan ini belum dapat digeneralisasi dengan alasan bahwa pemilihan sampel menggunakan teknik non probability sampling sehingga sampel kurang representatif; oleh karena itu dibutuhkan penelitian selanjutnya dengan sampel yang dapat mewakili populasi.

\section{F. REFERENSI}

Cavanagh, Michael E. (1982). The Counseling Experience, A Theoretical and Practical Approach. Belmont: Wadsworth.

Cavanagh, Michael E. dan Levitov, Justin E. (2002). The Counseling Experience, A Theoretical and Practical Approach. Long Grove: Waveland. 
Creswell, Jhon. W. (1994). Research Design. Qualitative \& Quantitative Approaches. California: SAGE Publication.

Fraenkel, Jack R. \& Wallen, Norman E. (1990). How to Design and Evaluate Research in Education. New York: McGraw-Hill,Inc.

Fuhrmann, Barbara Schneider. (1990). Adolescence, Adolescents (second ed.). Glenview: Scott, Foresman/Litle, Brown Higher Education.

Furqon. (2004). Statistika Terapan untuk Penelitian. Bandung: Alfabeta.

Gall, Meredith D., Gall, Joyce P., dan Borg, Walter R. (2003). Educational Research, An Introduction. Boston: Pearson Education Inc.

Heppner, P. Paul, Kivlighan, Dennis M., Jr., dan Wampold, Bruce E. (1992). Research Design in Counseling. Belmont: Wadsworth, Inc.

Heppner, P. Paul, Kivlighan, Dennis M., Jr., dan Wampold, Bruce E. (2008). Research Design in Counseling (third ed.). Belmont: Thomson Brooks/Cole.

Hurlock, Elizabeth B. (1973). Adolescent Development (forth ed.). Tokyo: McGraw-Hill Kogahusha, Ltd.
Hurlock, Elizabeth B. (1980). Psikologi Perkembangan. Suatu Pendekatan Sepanjang Rentang Kehidupan (edis i kelima). Jakarta: Erlangga.

McMillan, James and Schumacher, Sally. (2001). Research in Education. New York: Addison, Wesley Longman, Inc.

Santrock, John W. (2002). Life-Span Development, Perkembangan Masa Hidup Jilid 2 (edis i kelima ). Jakarta: Penerbit Erlangga.

Santrock, John W. (2007). Remaja Jilid 1 (edisi 11). Jakarta: Penerbit Erlangga.

Santrock, John W. (2007). Remaja Jilid 2 (edisi 11). Jakarta: Penerbit Erlangga. 